\title{
RESEARCH REGARDING CONSUMER PURCHASE AND NEED FOR VEGETABLE PRODUCTS IN THE KOSOVO MARKET
}

\author{
Isuf Lushi $^{{ }^{*}}$, Sadik Maloku ${ }^{1}$ \\ ${ }^{1 *}$ Faculty of life and environmental sciences, University "Ukshin HOTI” Prizren, Kosovo; \\ *Corresponding first author Isuf Lushi, e-mail: isuf.lushi@uni-prizren.com;
}

Received July 2020; Accepted August 2020; Published September 2020;

DOI: https://doi.org/10.31407/ijees10.408

\begin{abstract}
The study was conducted in five municipalities of Kosovo. Sampling was selected by random method. The data are provided through direct interviews with consumers of vegetable products, all of them, over 18 years of age. The results show that the vegetable products from tomato, pepper, cucumber, potato and cabbage are preferred to be consumed by almost all members of the Kosovo families with $100 \%$ of respondents. Consumption of processed vegetable products like pickles, ketchup and ajvar is accepted $100 \%$ by consumers. Super-markets and green markets are the favourite places for consumers when shopping for vegetable products. The main aim of our study was to investigate whether the consumption of vegetable products, is determined by the way of life of families and consumers, segmented by age, gender, occupation, income level, employment status, family size, etc. More than 3/4 of respondents stated that with the increase of their income, they are willing to spend more money to buy vegetable products. About 8/10 of consumers interviewed, have stated that they prefer vegetable products produced in Kosovo. During our study, as very important factors are shown: price, product quality and origin. Consumers pay greater attention to the production date and origin of the product. According to the results of the survey, consumers' participation in the purchase of vegetable products by gender was: males with $37 \%$, both genders (female and male) participated with $2 \%$ and the participation of females in the purchase of products is $61 \%$.
\end{abstract}

Keywords: vegetables, vegetable products, consumers. 